\title{
DETERMINAN KESEJAHTERAAN PELAKU UMKM KERAJINAN DI KOTA DENPASAR
}

\author{
"I Gde Wedana Arjawa ${ }^{1}$ dan I Nyoman Senimantara ${ }^{2}$ \\ ${ }^{1,2}$ Fakultas Ekonomi dan Bisnis Universitas Warmadewa Denpasar Bali \\ Email: wedamail02@gmail.com*
}

\begin{abstract}
Abstrak: Tujuan pembangunan ekonomi adalah untuk meningkatkan kesejahteraan masyarakat. Pertumbuhan ekonomi nasional sangat ditentukan oleh dinamika perekonomian daerah, sedangkan perekonomian daerah pada umumnya ditopang oleh kegiatan ekonomi bersakala UMKM dan salah satunya adalah sektor kerajinan. Pemberdayaan UMKM ditujukan untuk membuat kehidupan pelaku UMKM dapat hidup sejahtera. Untuk dapat mewujudkan kehidupan yang sejahtera, pelaku UMKM kerajinan di Kota Denpasar mempunyai banyak keterbatasan sehingga usaha ini belum mampu untuk berkembang secara optimal terlebih ditengah pandemi covid-19 yang melanda saat ini. Dari studi pustaka, diketahui bahwa peran pemerinatah, modal sosial, dan kinerja usaha berpengaruh terhadap kesejahteraan pelaku usaha. Tujuan dari penelitian ini adalah untuk menganalisis (1) pengaruh kinerja keuangan dan belanja modal terhadap kinerja perekonomian; (2) pengaruh kinerja keuangan, belanja modal dan kinerja perekonomian terhadap kesejahteraan masyarakat; dan (3) menganalisis pengaruh tak langsung kinerja keuangan dan belanja modal terhadap kesejahteraan masyarakat melalui kinerja perekonomian pada kabupaten kota di provinsi Bali. Penelitian ini dilakukan terhadap 97 sampel dan pengumpulan data dilakukan melalui kuesioner. Analisis data dilakukan dengan metode SEM-PLS. Hasil penelitian dan analisis data menunjukkan bahwa (1) peran pemerintah berpengaruh positif dan tidak signifikan, sedangkan modal sosial berpengaruh positif signifikan terhadap kinerja usaha; (2) peran pemerintah, modal sosial, dan kinerja usaha berpengaruh positif dan signifikan terhadap kesejahteraan pelaku usaha dan (3) peran pemerintah tidak berpengaruh tak langsung sedangkan modal social berpengaruh tak langsung terhadap kesejahteraan pelaku usaha melalui kinerja usaha.Peran pemerintah memegang peranan yang penting dalam pemberdayaan UMKM. Peran pemerintah belum mampu meningkatkan kinerja usaha namun mampu meningkatkan kesejahteraan pelaku usaha. Modal social mampu meningkatkatkan kinerja usaha dan kesejahteraan pelaku usaha dan kinerja usaha juga mampu memediasi hubungan modal social terhadap kesejahteraan pelaku UMKM di Kota Denpasar.

Kata kunci: peran pemerintah, modal social, kinerja usaha, kesejahteraan pelaku usaha, UMKM, Denpasar, Bali
\end{abstract}

\section{PENDAHULUAN}

Pertumbuhan ekonomi nasional sangat ditentukan oleh dinamika perekonomian daerah, sedangkan perekonomian daerah pada umumnya ditopang oleh kegiatan ekonomi bersakala mikro, kecil dan menengah. Unit usaha yang masuk dalam kategori usaha mikro, kecil dan menengah (UMKM) merupakan urat nadi perekonomian daerah dan nasional (Hamid, 2010).

Peran UMKM dalam perekonomian dapat dilihat dari (1) kedudukannya sebagai pemain utama dalam kegiatan ekonomi di berbagai sektor; (2) penyedia lapangan kerja yang terbesar; (3) pemain penting dalam pengembangan kegiatan ekonomi lokal dan pemberdayaan masyarakat; (4) pencipta pasar baru dan sumber inovasi; dan (5) sumbangannya dalam menjaga neraca pembayaran melalui kegiatan ekspor (Putra, 2016).

Kerajinan adalah salah satu usaha yang sebagian besar merupakan UMKM. Kerajinan yang berkembang di Kota Denpasar merupakan suatu bentuk perpaduan antara keterampilan tangan dengan nilai-nilai seni yang tak terpisahkan dari kebudayaan Bali. Inilah keunggulan komparatif kerajinan Bali sebagai salah satu dari sub sektor industri kreatif di Indonesia yang sangat potensial untuk ditingkatkan dan dikembangkan menjadi komoditi ekspor yang memiliki daya saing yang tinggi dalam pasar bebas. 
Kinerja ekspor hasil kerajinan dari Kota Denpasar untuk tahun 2015-2019 mengalami fluktuasi artinya mengalami penurunan dan peningkatan nilai ekspor. Nilai ekspor hasil kerajinan pada tahun 2015 tercatat sebesar Rp 1.976 .515 juta dan mengalami kenaikan berturut-turut dari tahun 2016 sebesar Rp 2.115.180 juta dan tahun 2017 sebesar Rp 2.440 .392 juta. Namun nilai realisasi ekspor hasil kerjinan menurun pada tahun 2018 menjadi Rp 2.295.146 juta dan kemudian menuru drastis menjadi Rp 1.945.296 juta pada tahun 2019.

Penurunan kinerja ekspor ini perlu mendapatkan perhatian karena kontribusi ekspor hasil kerajinan sangat berpengaruh pada pertumbuhan ekonomi di Kota Denpasar. Oleh karena itu, perlu dilakukan penelitian untuk mengkaji dan menganalisis permasalahan penyebab menurunnya kinerja ekspor tersebut sebagai evaluasi agar ekspor dari Kota Denpasar tetap mempunyai daya saing dalam menghadapi era globalisasi dan kinerja ekspor ini akan berpengaruh secara langsung terhadap kesejahteraan pelaku UMKM kerajinan.

Tujuan dari penelitian ini adalah untuk menganalisis (1) pengaruh kinerja keuangan dan belanja modal terhadap kinerja perekonomian; (2) pengaruh kinerja keuangan, belanja modal dan kinerja perekonomian terhadap kesejahteraan masyarakat; dan (3) menganalisis pengaruh tak langsung kinerja keuangan dan belanja modal terhadap kesejahteraan masyarakat melalui kinerja perekonomian pada kabupaten kota di provinsi Bali.

\section{KAJIAN PUSTAKA Kesejahteraan}

Ismail, dkk. (2015) mengatakan bahwa kesejahteraan merupakan konsep yang abstrak karena keberadaannya terkait langsung dengan nilai-nilai hidup dan ideology yang dianut oleh seseorang. Kesejahteraan tidak hanya diartikan sebagai ukuran ketersediaan material, tetapi perlu dikaitkan dengan pandangan hidup bangsa yang dianut. Kesejahteraan bukan hanya menjadi cita-cita individu secara perorangan, namun juga menjadi tujuan sekumpulan individu yang terhimpun dalam suatu negara sehingga muncul dua macam kesejahteraan yaitu kesejahteraan individu dan kesejahteraan masyarakat.

Menurut Friedlander (1980) bahwa kesejahteraan merupakan sistem yang terorganisasi yang dilakukan melalui pelayanan-pelayanan dan lembaga-lembaga sosial dengan tujuan untuk membantu individu dan kelompok agar mencapai tingkat hidup dan kesehatan yang memuaskan serta hubungan-hubungan personal dan sosial yang memberi kesempatan untuk mengembangkan seluruh kemampuannya dan untuk meningkatkan kesejahteraannya sesuai dengan kebutuhan-kebutuhan keluarga dan masyarakat.

Inti kesejahteraan menurut Sen (2006) adalah kapabilitas. Pengembangan kamampuan (kapabilitas) manusia berkaitan dengan peningkatan harapan hidup, bebas dari buta huruf, kesehatan dan pendidikan. Kapabilitas memungkinkan manusia untuk dapat menjalani hidup yang lebih bermakna (sejahtera). Kesejahteraan subjektif (subjective well-being) dapat diketahui dari ada atau tidaknya perasaan bahagia (Luthans et al., 2007). Ketika seseorang menilai lingkungan kerja sebagai lingkungan yang menarik, menyenangkan dan penuh dengan tantangan dapat dikatakan bahwa ia merasa bahagia dan menunjukkan kinerja yang optimal (Wright \& Bonett, 2007).

Seseorang dikatakan memiliki kesejahteraan subjektif yang tinggi jika orang tersebut merasa puas dengan kondisi hidupnya, sering merasakan emosi positif dan 
jarang merasakan emosi negatif. Ketika seseorang mencirikan suatu kehidupan baik ia akan banyak membicarakan tentang kebahagiaan, kesehatan, dan umur yang panjang (Diener \& Chan, 2011). Siedlecki (2013) mengartikan kesejahteraan subjektif sebagai gagasan dari keputusan kognitif yang mencerminkan kepuasan hidup seseorang dan sebuah evaluasi emosi yang digolongkan menjadi emosi positif dan emosi negatif.

Menurut OECD/Organisation for Economic Co-operation and Development (2013), indikator kesejahteraan subyektif dapat dilihat antara lain dari terpenuhinya kebutuhan hidup, terpenuhinya biaya berobat (kesehatan), terpenuhinya cita-cita hidup; terpenuhinya rasa aman pribadi, mempunyai hubungan baik antar pribadi, mempunyai hubungan baik dengang komunitas lain, mempunyai tabungan untuk masa depan, dan dapat melakukan kegiatan keagamaan dengan baik.

\section{Kinerja Usaha}

Keats \& Hitt (1988) menyatakan bahwa penilaian terhadap kinerja memiliki nilai penting karena, selain dapat dipergunakan sebagai ukuran keberhasilan lembaga dalam periode tertentu, Penilaian kinerja dapat juga dijadikan umpan balik untuk perbaikan atau peningkatan kinerja di masa yang akan datang, Oleh karena itu, penilaian terhadap kinerja suatu lembaga harus dilakukan, karena hasil penilaian ini dapat dijadikan dasar informasi untuk melakukan perbaikan kinerja usaha untuk masa-masa kedepannya. Kinerja perusahaan merupakan sesuatu yang dihasilkan oleh perusahaan dalam periode tertentu dengan mengacu pada standar yang ditetapkan.

Penilaian kinerja perusahaan merupakan suatu proses berkaitan dengan penilaian pelaksanaan prestasi kemampuan kerja organisasi berdasarkan standar tertentu (Kaplan \& Norton, 1996 ; Brandon \& Drtina, 1997). Kinerja pelaku usaha menunjuk kepada tingkat kemampuan pengusaha melaksanakan perkerjaannya. Pelaku usaha dikatakan memiliki kinerja yang baik bila berkaitan dan memenuhi standar tertentu. Dari model tersebut, faktor motivasi dan kemampuan merupakan faktor penting dalam menentukan kinerja usaha (Dukat \& Yuniatie, 2015).

Menurut Munizu (2010) ada beberapa inikator kinerja usaha yang dapat dipakai untuk mengukur kinerja usaha yang dipergunakan dalam penelitian ini (1) pertumbuhan penjualan yaitu terjadinya peningkatan jumlah penjualan dari periode sebelumnya; (2) pertumbuhan keuntungan yaitu terjadinya peningkatan jumlah keuntungan dari periode sebelumnya; dan (3) pertumbuhan pangsa pasar yaitu terjadinya peningkatan jumlah pelanggan dari periode sebelumnya.

Penelitian terkait pengaruh kinerja UMKM terhadap kesejahteraan pelaku UMKM telah dilakukan oleh beberapa peneliti diantaranya Gandhiadi et al., (2018), Irviani (2017) dan Eddy (2020) bahwa kinerja usaha berpengaruh positif dan signifikan terhadap kesejahteraan, sehingga dapat dikatakan bahwa peningkatan kinerja usaha dengan indikatornya akan mengakibatkan pengaruh langsung pada peningkatan kesejahteraan.

\section{Peran Pemerintah}

Peran pemerintah dalam kegiatan pembangunan adalah untuk menyediakan layanan dan bantuan teknis serta dukungan eksternal bagi masyarakat. Layanan dan dukungan pemerintah yang disampaikan kepada masyarakat telah memberikan kontribusi besar terhadap pembangunan ekonomi, infrastruktur, dan kualitas kehidupan masyarakat. Namun demikian bantuan teknis tersebut perlu disikapi secara berhati-hati, karena sisi negatif yang ditimbulkannya yakni dapat membatasi kapasitas masyarakat 
dan mengakibatkan ketergantungan serta menekan organisasi lokal dan kepemimpinan (Kretzmann \& McKnight, 1993).

Menurut Sudaryanto (2011), pemberdayaan UMKM di tengah arus globalisasi dan tingginya persaingan membuat UMKM harus mampu mengadapai tantangan global, seperti meningkatkan inovasi produk dan jasa, pengembangan sumber daya manusia dan teknologi, serta perluasan area pemasaran. Hal ini perlu dilakukan untuk menambah nilai jual UMKM itu sendiri, utamanya agar dapat bersaing dengan produk-produk asing yang kian membanjiri sentra industri dan manufaktur di Indonesia, mengingat UMKM adalah sektor ekonomi yang mampu menyerap tenaga kerja terbesar di Indonesia.

Peran pemerintah dalam penelitian ini didefinisikan sebagai peran untuk menyediakan layanan dan dukungan eksternal bagi masyarakat. Peran pemerintah diharapkan mampu mengangkat tingkat kesejahteraan pelaku usaha. Menurut (Muhammad, Nurmaeta, and Tahir 2014); (Gulbrandsen 2014) dan (Steurer 2010), peran pemerintah dalam memberdayaakan UMKM diwujudkan sebagai regulator, dinamisator dan fasilitator.

Penelitian Korry (2013) menyatakan bahwa kebijakan pemerintah sangat berperan pada kinerja bisnis Koperasi Unit Desa di Provinsi Bali. Peningkatan pada kualitas kebijakan distributif dan regulatif pemerintah mampu mendorong peningkatan kinerja bisnis. Begitu juga dengan hasil penelitian Lee dan Tsang (2011) dan Munizu (2010) menyebutkan bahwa kebijakan pemerintah memiliki pengaruh strategis pada kinerja bisnis. Hal yang berbeda dihasilkan oleh pelitian Arjawa, et.al (2016) yang dilakukan terhadap UKM Kerajinan di Provinsi Bali bahwa Peran Pemerintah secara langsung berpengaruh tidak signifikan terhadap kinerja usaha.

Pemerintah memiliki peran strategis dalam pemberdayaan UMKM di Indonesia. UMKM memiliki peran penting dalam proses pertumbuhan ekonomi negara dan untuk itu upaya pengembangan UMKM perlu dilakukan oleh pemerintah. Oleh sebab itu peran pemerintah menjadi penting bagi peningkatan kinerja UMKM untuk dapat bersaing di pasar global dalam rangka meningkatkan kesejahteraan pelaku UMKM (Simamora and Sinaga 2016; Adi 2017; Swastika, et al, 2017; Agustina 2019).

\section{Modal Sosial}

Di era globalisasi saat ini dan perekonomian dunia di pasar bebas, semakin terlihat jelas bahwa peran human capital dalam sistem perekonomian semakin menurun. Modal ini, yang disebut modal sosial, adalah kemampuan masyarakat untuk bekerja sama untuk mencapai tujuan bersama bagi kelompok dan organisasi (Coleman, 1988).

Modal sosial dapat berdampak pada kewirausahaan dan kesejahteraan serta meningkatkan kesejahteraan perusahaan, seperti yang ditunjukkan oleh Farsi (2013), sebuah survei terhadap manajer senior di pabrik suku cadang mobil di Iran. .. Durojaiye dkk. (2013) melakukan penelitian tentang dampak modal sosial terhadap pertumbuhan laba toko kelontong di Nigeria dan menunjukkan bahwa modal sosial berperan aktif dan penting dalam meningkatkan laba dari penjualan makanan Nigeria. Hasil penelitian Yuliarmi dkk. (2020) menyimpulkan bahwa modal sosial dan pemberdayaan koperasi berpengaruh positif dan signifikan terhadap kesejahteraan anggota badan usaha koperasi di kota Denpasar. Fukuyama (1999) mendefinisikan modal sosial sebagai seperangkat nilai atau norma informal yang memungkinkan anggota kelompok untuk berbagi dan berkolaborasi. Putnam (1993) memberikan definisi modal sosial adalah munculnya organisasi sosial seperti kepercayaan, timbal balik, dan jaringan yang dapat 
meningkatkan efisiensi masyarakat dengan memfasilitasi koordinasi dan kolaborasi untuk saling menguntungkan. Riddell (1997) menyatakan bahwa ada tiga indikator modal sosial: (1) kepercayaan (2) norma, dan (3) jaringan yang dapat digunakan untuk mengukur modal sosial pelaku UMKM.

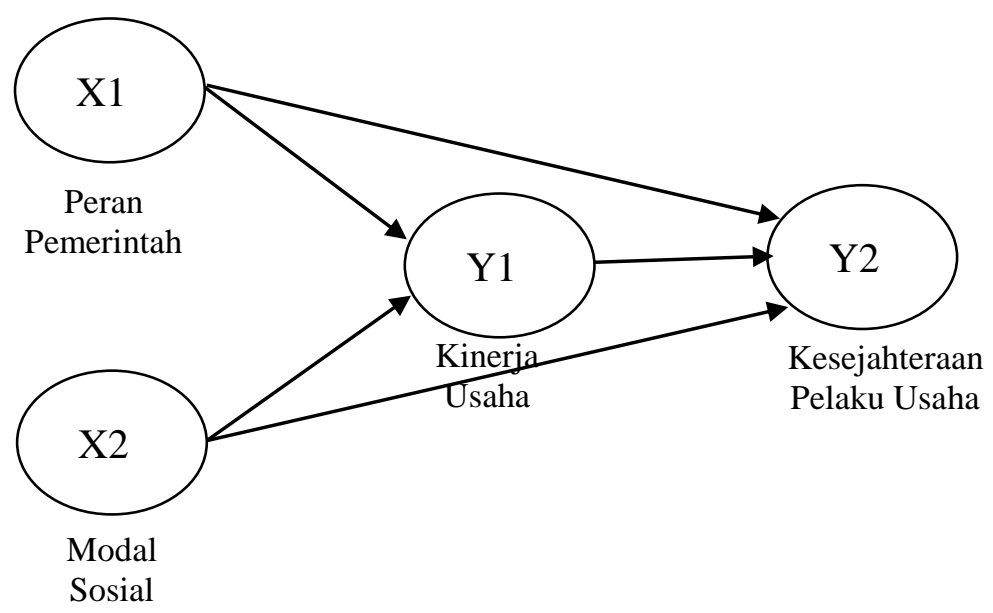

Gambar. 1

Kerangka Konsep Penelitian

\section{HIPOTESIS}

1) Peran pemerintah dan modal sosial berpengaruh positif terhadap kinerja usaha pelaku UMKM kerajinan di Kota Denpasar.

2) Peran pemerintah, modal sosial dan kinerja usaha berpengaruh positif terhadap kesejahteraan pelaku UMKM kerajinan di Kota Denpasar.

3) Kinerja usaha memediasi hubungan peran pemerintah dan modal sosial terhadap kesejahteraan pelaku UMKM kerajinan di Kota Denpasar.

\section{METODE PENELITIAN}

Populasi dalam penelitian ini 88 orang pelaku UMKM kerajinan di Kota Denpasar Bali. Semua populasi menjadi sampel. Data yang digunakan dalam penelitian ini adalah data primer, yaitu berupa data-data yang diperoleh langsung responden. Pengumpulan data dalam penelitian ini menggunakan metode survei melalui kuesioner. Pengolahan dan analisis data dilakukan dengan bantuan software Smart PLS.

Tabel 1

Identifikasi Variabel

\begin{tabular}{cclll}
\hline No & $\begin{array}{c}\text { Jenis } \\
\text { Variabel }\end{array}$ & Nama Variabel & & \multicolumn{1}{c}{ Indikator } \\
\hline 1. & Eksogen & Peran & X11: & Regulator \\
& & Pemerintah $(X 1)$ & X12: & Dinamisator \\
& & & X13: & Fasilitator \\
2. Eksogen & Modal & X21: & Kepercayaan \\
& & Sosial(X2) & X22: & Norma \\
& & X23: & Jaringan \\
3. Mediasi & Kinerja & Y11: & Penjualan
\end{tabular}


Usaha (Y1) Y12: Keuntungan

Y13: Pangsa pasar

4. Endogen Kesejahteraan

Y21: Terpenuhi kebutuhan pokok

Pelaku Usaha

(Y2)
Y22: Terpenuhi kebutuhan pendidikan

Y23: Dapat melaksanakan kegiatan agama dengan baik

Sumber : Diolah (2021)

\section{ANALISIS DATA DAN PEMBAHASAN}

\section{Uji Validitas Konstruk}

Pada uji validitas kovergen berdasarkan loading factor disajikan pada Gambar 1 dan terlihat semua indikator mempunyai loading factor di atas 0,7 terhadap konstruk yang dituju.

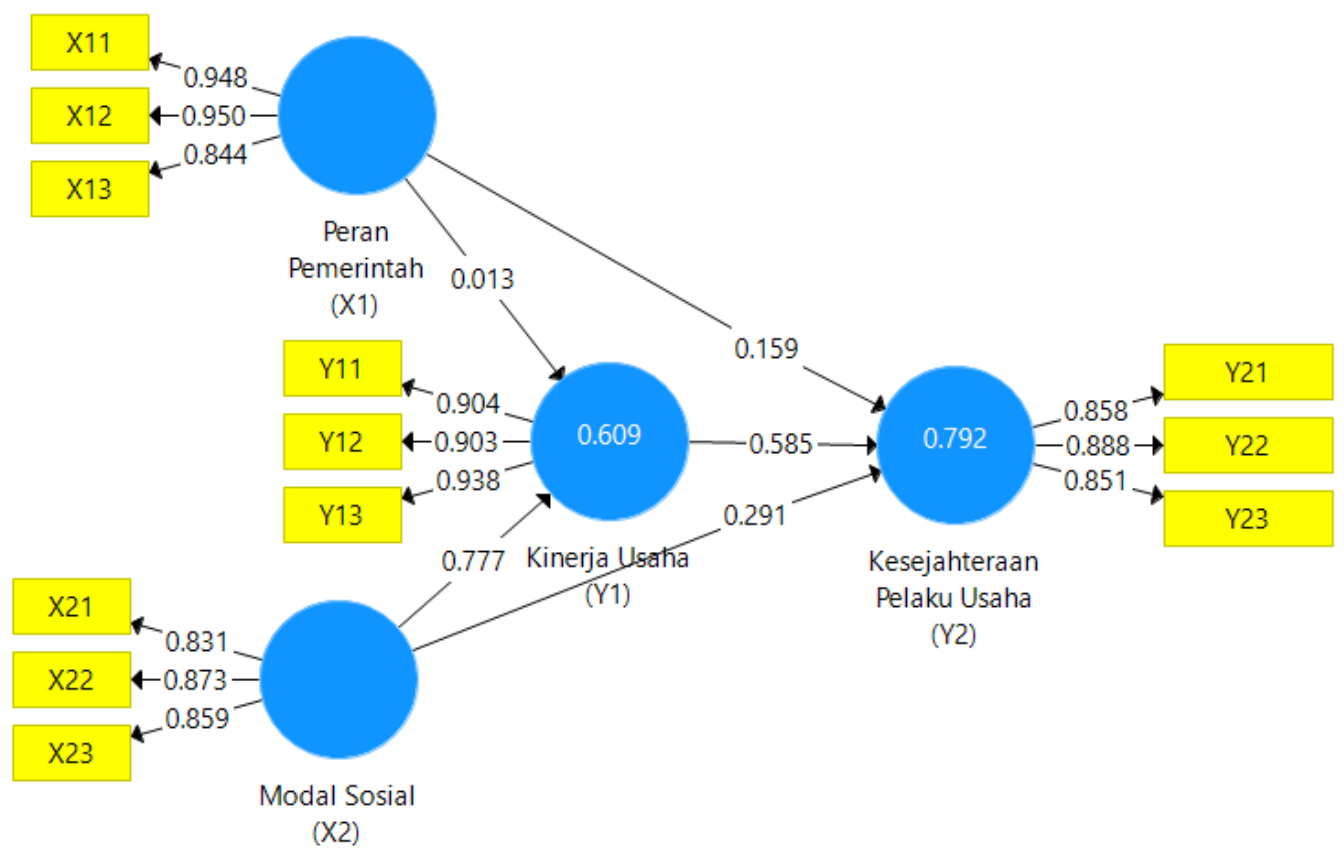

Gambar 1

Full Model Struktural

a. Uji Loadings Factor

Tabel 2

Loading Factor

\begin{tabular}{lcccc}
\hline & $\begin{array}{c}\text { Original } \\
\text { Sample }\end{array}$ & $\begin{array}{c}\text { Standard } \\
\text { Deviation }\end{array}$ & T Statistics & P Values \\
\hline $\mathrm{X} 11<-\mathrm{X} 1$ & 0.948 & 0.027 & 35.687 & 0.000 \\
$\mathrm{X} 12<-\mathrm{X} 1$ & 0.950 & 0.018 & 52.316 & 0.000 \\
$\mathrm{X} 13<-\mathrm{X} 1$ & 0.844 & 0.103 & 8.192 & 0.000 \\
$\mathrm{X} 21<-\mathrm{X} 2$ & 0.831 & 0.045 & 18.501 & 0.000 \\
$\mathrm{X} 22<-\mathrm{X} 2$ & 0.873 & 0.031 & 28.357 & 0.000 \\
$\mathrm{X} 23<-\mathrm{X} 2$ & 0.859 & 0.027 & 31.695 & 0.000 \\
$\mathrm{Y} 11<-\mathrm{Y} 1$ & 0.904 & 0.023 & 40.032 & 0.000 \\
$\mathrm{Y} 12<-\mathrm{Y} 1$ & 0.903 & 0.022 & 41.241 & 0.000 \\
\hline
\end{tabular}




\begin{tabular}{lllll}
\hline Y13 <- Y1 & 0.938 & 0.015 & 63.591 & 0.000 \\
Y21 <- Y2 & 0.858 & 0.034 & 25.541 & 0.000 \\
Y22 <- Y2 & 0.888 & 0.025 & 35.111 & 0.000 \\
Y23 <- Y2 & 0.851 & 0.041 & 20.969 & 0.000 \\
\hline
\end{tabular}

Pada Tabel 2 terlihat bahwa seluruh indikator untuk semua konstruk memiliki loading factor (original sample) di atas 0,7. Dengan demikian dapat dinyatakan bahwa semua indikator valid merefleksikan masing-masing konstruknya.

\section{b. Uji Fornell-Larcker Criterion}

Tabel 3

\begin{tabular}{|c|c|c|c|c|}
\hline \multicolumn{5}{|c|}{ Uji Fornell-Larcker Criterion } \\
\hline $\mathrm{X} 1$ & 0.927 & & & \\
\hline $\mathrm{X} 2$ & 0.120 & 0.854 & & \\
\hline Y1 & 0.121 & 0.787 & 0.914 & \\
\hline Y2 & 0.219 & 0.798 & 0.866 & 0.856 \\
\hline
\end{tabular}

Tabel 3 menunjukkan bahwa nilai atas AVE terhadap variabelnya lebih besar dari korelasi variabel laten lainnya. Dengan demikian dari hasil uji Fornell-Larcker Criterion atas dapat dinyatakan bahwa konstruk dinyatakan valid.

\section{c. Uji Cross Loadings (muatan silang)}

Tabel 4

\begin{tabular}{ccccc}
\multicolumn{5}{c}{ Cross Loading Uji Variabel Penelitian } \\
\hline & X1 & X2 & Y1 & Y2 \\
\hline X11 & 0.948 & 0.309 & 0.233 & 0.400 \\
X12 & 0.950 & 0.295 & 0.271 & 0.397 \\
X13 & 0.844 & 0.175 & 0.124 & 0.212 \\
X21 & 0.296 & 0.831 & 0.655 & 0.671 \\
X22 & 0.320 & 0.873 & 0.588 & 0.657 \\
X23 & 0.158 & 0.859 & 0.744 & 0.707 \\
Y11 & 0.274 & 0.677 & 0.904 & 0.787 \\
Y12 & 0.236 & 0.718 & 0.903 & 0.813 \\
Y13 & 0.158 & 0.746 & 0.938 & 0.736 \\
Y21 & 0.349 & 0.626 & 0.677 & 0.858 \\
Y22 & 0.405 & 0.726 & 0.782 & 0.888 \\
Y23 & 0.251 & 0.708 & 0.746 & 0.851 \\
\hline
\end{tabular}

Tabel 4 menunjukkan bahwa masing-masing indikator memiliki nilai cross loading tertinggi terhadap variabel latennya. Hal ini menunjukkan bahwa seluruh indikator adalah memenuhi discriminant validity pada pengujian Cross Laodings. Artinya, semua indikator layak diikutsertakan pada analisis lanjut. 


\section{Uji Reliablitas Konstruk}

Tabel 5

Uji Reliabilitas Konstruk

\begin{tabular}{cccc}
\hline & $\begin{array}{c}\text { Cronbach's } \\
\text { Alpha }\end{array}$ & $\begin{array}{c}\text { Composite } \\
\text { Reliability }\end{array}$ & $\begin{array}{c}\text { Average } \\
\text { Variance } \\
\text { Extracted } \\
\text { (AVE) }\end{array}$ \\
\hline X1 & 0.907 & 0.939 & 0.838 \\
X2 & 0.816 & 0.890 & 0.731 \\
Y1 & 0.903 & 0.939 & 0.837 \\
Y2 & 0.833 & 0.900 & 0.750 \\
\hline
\end{tabular}

Pada Tabel 5 terlihat nilai Cronbach's Alpha, ,Composite Reliability dan Average Variance Extracted (AVE) untuk masing-masing konstruk semuanya bernilai lebih besar dari 0,70 dan AVE lebih besar dari 0,5, dengan demikian seluruh variabel dalam penelitian ini adalah reliabel.

\section{Pengujian Kecocokan Model (Evaluasi Goodness of Fit Inner Model)}

Model struktural hasil pengolahan PLS perlu dievaluasi dengan menggunakan $R$-square untuk setiap variabel dependen, dan $Q$ square predictive relevance untuk melihat efek konstruk laten eksogen terhadap variabel endogennya. Untuk keperluan evaluasi Goodness of Fit Inner Model ditampilkan pada Tabel 6 yang memuat koefisien $R$-square untuk setiap variabel endogen.

$$
\text { Tabel } 6
$$

\begin{tabular}{lc}
\multicolumn{2}{c}{ Nilai R-square Variable } \\
\hline Variabel & R Square \\
\hline Kinerja Usaha (Y1) & 0,609 \\
Kesejahteraan Pelaku Usaha (Y2) & 0,792 \\
\hline
\end{tabular}

Berdasarkan dua koefisien $\mathrm{R}^{2}$ pada Tabel 6 dapat pula dihitung besarnya koefisien $\mathrm{Q}^{2}$ atau Stone Geiser Q-Square test (Ghozali, 2011), yaitu.

$$
\begin{aligned}
& \mathrm{Q}^{2}=1-\left\{\left(1-\mathrm{R}_{1}{ }^{2}\right)\left(1-\mathrm{R}_{2}{ }^{2}\right)\right\} \\
& \mathrm{Q}^{2}=1-\{(1-0,620)(1-0,797)\} \\
& \mathrm{Q}^{2}=0,905
\end{aligned}
$$

Berdasarkan hasil perhitungan predictive relevance $\left(\mathrm{Q}^{2}\right)$ di atas, menunjukkan nilai 0,905. Dalam model penelitian ini, variabel laten endogen memiliki nilai predictive relevance $\left(\mathrm{Q}^{2}\right)$ yang lebih besar dari 0 (nol) sehingga variabel laten eksogen sesuai sebagai variable penjelas yang mampu memprediksi variabel endogennya atau dengan kata lain membuktikan bahwa model ini dinilai memiliki predictive relevance yang baik digunakan untuk melakukan prediksi.

\section{Pengaruh Langsung dan Pengaruh Tak Langsung}

Untuk mengetahui pengaruh langsung antar variabel konstruk dapat dilihat dari hasil analisis nilai path coefficients yang ditampilkan pada Tabel 7. 
Tabel 7

Path Coefficients, T-Statistics, P-Values

\begin{tabular}{lcccl}
\hline & $\begin{array}{c}\text { Original } \\
\text { Sample }\end{array}$ & T Statistics & P Values & Signifikansi \\
\hline X1 -> Y1 & 0.013 & 0.146 & 0.884 & Tidak Signifikan \\
X1 -> Y2 & 0.159 & 2.731 & 0.007 & Signifikan \\
X2 -> Y1 & 0.777 & 12.906 & 0.000 & Signifikan \\
X2 -> Y2 & 0.291 & 3.364 & 0.001 & Signifikan \\
Y1 -> Y2 & 0.585 & 7.479 & 0.000 & Signifikan \\
\hline
\end{tabular}

Untuk mengetahui pengaruh tidak langsung antar variabel konstruk dapat dilihat dari hasil analisis nilai indirect effects yang ditampilkan pada Tabel 8.

Tabel 8

Nilai Indirect Effects

\begin{tabular}{lcccl}
\hline & $\begin{array}{c}\text { Original } \\
\text { Sample }\end{array}$ & $\begin{array}{c}\text { T } \\
\text { Statistics }\end{array}$ & $\begin{array}{c}\text { P } \\
\text { Values }\end{array}$ & \multicolumn{1}{c}{ Signifikansi } \\
\hline $\mathrm{X} 1$-> Y1 -> Y2 & 0.007 & 0.145 & 0.884 & $\begin{array}{l}\text { - Tidak Signifikan } \\
\text { - Tidak Memediasi }\end{array}$ \\
X2 -> Y1 -> Y2 & 0.455 & 6.875 & 0.000 & $\begin{array}{l}\text { - Signifikan } \\
\text { - Mediasi sebagian }\end{array}$ \\
\hline
\end{tabular}

\section{Pengujian Hipotesis}

1) Hipotesis 1: Peran pemerintah dan modal sosial berpengaruh positif terhadap kinerja usaha UMKM kerajinan di Kota Denpasar.

Berdasarkan hasil olahan data diketahui bahwa (1) pengaruh peran pemerintah terhadap kinerja usaha memiliki koefisien regresi sebesar 0,026, dan tingkat signifikansi berupa Pvalue sebesar 0,742. Hal ini menunjukkan peran pemerintah berpengaruh positif dan tidak signifikan terhadap kinerja usaha UMKM kerajinan di Kota Denpasar dan hipotesis ditolak; (2) pengaruh modal social terhadap kinerja usaha memiliki koefisien regresi sebesar 0,784, dan tingkat signifikansi berupa Pvalue sebesar 0,000. Hal ini menunjukkan modal sosial berpengaruh positif dan signifikan terhadap kinerja usaha UMKM kerajinan di Kota Denpasar dan hipotesis diterima.

\section{2) Hipotesis 2: Peran pemerintah, modal sosial dan kinerja usaha berpengaruh positif terhadap kesejahteraan pelaku UMKM kerajinan di Kota Denpasar.}

Berdasarkan hasil olahan data diketahui bahwa (1) pengaruh peran pemerintah terhadap kesejahteraan pelaku usaha memiliki koefisien regresi sebesar 0,108, dan tingkat signifikansi berupa Pvalue sebesar 0,034. Hal ini menunjukkan peran pemerintah berpengaruh positif dan signifikan terhadap kesejahteraan pelaku usaha UMKM kerajinan di Kota Denpasar dan hipotesis diterima; (2) pengaruh modal terhadap kesejahteraan pelaku usaha memiliki koefisien regresi sebesar 0,300, dan tingkat signifikansi berupa Pvalue sebesar 0,000. Hal ini menunjukkan modal social berpengaruh positif dan signifikan terhadap kesejahteraan pelaku usaha UMKM 
kerajinan di Kota Denpasar dan hipotesis diterima; dan (3) pengaruh kinerja usaha terhadap kesejahteraan pelaku usaha memiliki koefisien regresi sebesar 0,617 dan tingkat signifikansi berupa Pvalue sebesar 0,000. Hal ini menunjukkan kinerja usaha berpengaruh positif dan signifikan terhadap kesejahteraan pelaku usaha UMKM kerajinan di Kota Denpasar dan hipotesis diterima.

\section{3) Hipotesis 3: Kinerja usaha memediasi hubungan peran pemerintah dan modal sosial terhadap kesejahteraan pelaku UMKM kerajinan di Kota Denpasar.}

Berdasarkan hasil olahan data diketahui bahwa (1) pengaruh tidak langsung peran pemerintah terhadap kesejahteraan pelaku usaha melalui kinerja usaha memiliki koefisien regresi sebesar 0,016 dan tingkat signifikansi berupa Pvalue sebesar 0,747. Artinya, secara tidak langsung peran pemerintah berpengaruh positif dan tidak signifikan terhadap kesejahteraan pelaku usaha melalui kinerja usaha UMKM kerajinan di Kota Denpasar dan hipotesis ditolak. Peran pemerintah berpengaruh langsung dan tidak signifikan terhadap kinerja usaha, kinerja usaha berpengaruh langsung dan signifikan terhadap kesejahteraan pelaku usaha dan peran pemerintah berpengaruh langsung dan signifikan terhadap kesejahteraan pelaku usaha. Sifat mediasi dalam hubungan ini adalah no mediatioan. Hal ini menunjukkan bahwa kinerja usaha tidak memediasi hubungan peran pemerintah terhadap kesejahtaeraan pelaku usaha; (2) pengaruh tidak langsung modal social terhadap kesejahteraan pelaku usaha melalui kinerja usaha memiliki koefisien regresi sebesar 0,483 dan tingkat signifikansi berupa Pvalue sebesar 0,000. Artinya, secara tidak langsung modal social berpengaruh positif dan signifikan terhadap kesejahteraan pelaku usaha melalui kinerja usaha UMKM kerajinan di Kota Denpasar dan hipotesis diterima. Modal social berpengaruh langsung dan signifikan terhadap kinerja usaha, kinerja usaha berpengaruh langsung dan signifikan terhadap kesejahteraan pelaku usaha dan modal social berpengaruh langsung dan signifikan terhadap kesejahteraan pelaku usaha. Sifat mediasi dalam hubungan ini adalah mediasi parsial. Hal ini menunjukkan bahwa peningkatan modal social terhadap kesejahteraan pelaku usaha dapat dilakukan secara langsung dan bisa juga dilakukan melalui mediasi kinerja usaha.

\section{PEMBAHASAN}

\section{Pengaruh langsung peran pemerintah terhadap kinerja usaha}

Hasil uji hipotesis penelitian ini menunjukkan bahwa peran pemerintah berpengaruh positif tetapi tidak signifikan terhadap kinerja usaha. Temuan ini, menjastifikasi bahwa peran pemerintah belum mampu meningkatkan secara signifikan kinerja usaha UMKM kerajinan di Kota Denpasar. Peran pemerintah direfleksikan paling dominan oleh fasilitator, disusul selanjutnya oleh regulator dan dinamisator. Indikator penjulan berperan paling dominan dalam merefleksikan konstruk kinerja usaha, selebihnya ditentukan oleh keuntungan dan pangsa pasar. Hasil penelitian ini mengindikasikan bahwa fungsi dan peran pemerintah belum mampu memberikan makna pada kkinerja usaha kinerja usaha UMKM kerajinan di Kota Denpasar. Belum 
signifikannya pengaruh peran pemerintah terhadap kinerja usaha UMKM kerajinan di Kota Denpasar ini bukan berarti pemerintah tidak diperlukan. Peran pemerintah masih sangat diperlukan dan ini dapat dilihat dari hasil olah data yang menunjukkkan bahwa ternyata bahwa peran pemerintah memiliki nilai outer loading yang bermakna.

Penelitian ini sejalan dengan penelitian Yuliarmi et al., (2012) yang menyimpulkan bahwa peran pemerintah melalui instansi terkait belum mampu secara langsung mempengaruhi pemberdayaan IKM di provinsi Bali dan juga didukung oleh penelitian Arjawa, et.al (2016) yang dilakukan terhadap UKM Kerajinan di Provinsi Bali bahwa peran pemerintah secara langsung berpengaruh tidak signifikan terhadap kinerja usaha.

\section{Temuan dan Kontribusi Penelitian}

Temuan dalam penelitian ini adalah pemerintah belum mampu meningkatkan kinerja usaha namun mampu meningkatkan kesejahteraan pelaku usaha UMKM kerajinan di Kota Denpasar. Kinerja usaha tidak memediasi hubungan peran pemerintah dan kesejahteraan pelaku usaha. Hasil penelitian ini secara empirik membuktikan bahwa konsepsi kinerja usaha dapat memediasi modal sosial terhadap kesejahteraan pelaku usaha UMKM kerajinan di Kota Denpasar. Hasil penelitian ini dapat dijadikan landasan untuk menyusun program, kebijakan, dan strategi untuk kesejahteraan masyarakat.

\section{Keterbatasan Penelitian}

Keterbatasan-keterbatasan yang dapat diidentifikasi terkait penelitian ini, yaitu sebagai berikut.

1) Penelitian ini hanya berlaku satu periode waktu pada saat penelitian sehingga hasil penelitian ini tidak bisa menggambarkan perilaku yang sama pada tahun mendatang dan untuk itu diperlukan riset longitudinal data di masa mendatang.

2) Hubungan peran pemerintah terhadap modal sosial tidak dibahas dalam penelitian ini sehingga tidak ada gambaran mengenai hubungan antara peran pemerintah terhadap modal sosial begitu juga hubungan sebaliknya.

\section{SIMPULAN DAN SARAN}

\section{Simpulan}

Berdasarkan hasil penelitian dan pembahasan yang telah diuraikan sebelumnya, dapat ditarik simpulan sebagai berikut.

1) Peran pemerintah berpengaruh positif dan signifikan sedangkan modal social berpengaruh positif signifikan terhadap kinerja usaha UMKM kerajinan di Kota Denpasar.

2) Peran pemerintah, modal social dan kinerja usaha berpengaruh positif dan signifikan terhadap kesejahteraan pelaku UMKM kerajinan di Kota Denpasar.

3) Kinerja usaha tidak memediasi hubungan peran pemerintah namun memediasi hubungan modal social terhadap kesejahteraan pelaku usaha UMKM kerajinan di Kota Denpasar. 
Jurnal Cahaya Mandalika, Vol. 3, No. 1, 2022 ,e- ISSN: 2721-4796

Available online at: http://ojs.cahayamandalika.com/index.php/JCM

Copyright @ 2021 Publisher: Institut Penelitian \& Pengembangan Mandalika Indonesia

\section{Saran}

Peran pemerintah belum mampu untuk memberikan makna pada kinerja usaha UMKM kerajinan di Kota Denpasar dan indikator pangsa pasar mendapat apreasiasi terendah dari responden dan untuk itu perlu ditingkatkan agar dapat memberikan makna di masa mendatang. Modal social perlu meningkatkan peran indicator kepercayaan agar terus dapat memberikan makna pada peningkatan kesejahteraan kesejahteraan pelaku usaha UMKM kerajinan di Kota Denpasar.

\section{DAFTAR PUSTAKA}

Agustina, Made Dian Putri. 2019. Pengaruh Peran Pemerintah, Partisipasi Masyarakat Dan Modal Sosial Terhadap Kualitas Destinasi Dan Kesejahteraan Masyarakat Di Desa Wisata Kabupaten Badung Provinsi Bali. Disertasi. Denpasar: Denpasar Universitas Udayana.

Ahmad, M. .. 2012. "Impact of Organizational Culture on Performance Management Practices in Pakistan.” Business Intelligence Journal 5(1):50-55.

Arjawa, I. Gde Wedana, Nyoman Djinar Setiawina, Made Kembar Sri Budhi, and I. Gde Sudjana Budiasa. 2016. "The Role of Government, Social Capital and Entrepreneurial Orientation to Export Performance of Craft SME at Bali Province." European Journal of Business and Management 8(27):105-14.

Badan Pusat Statistik. 2014. Indikator Kesejahteraan Masyarakat 2014. Badan Pusat Statistik Jakarta

Bourdieu, P. 1986. The Forms of Capita. New York: New York: Grewood Press.

Brandon., C and E. Drtina. 1997. Management Accounting: Strategy and Control. Canada: Canada : McGraw Hill Companies. Inc.

Coleman, J. S. 1988. "Social Capital in the Creation of Human Capital." American Journal of Sociology 94:S95-120.

Dukat, Sukanata I. Ketut, and Angie Yuniatie. 2015. "Hubungan Karakteristik Dan Motivasi Petani Dengan Kelompok Tani.” Jurnal Agrijati 28(1):17-34.

Durojaiye, AM. Yusuf S.A. Falusi A.O. and Okoruwa V O. 2013. Social Capital and Its Influence on Profitability of Foodstuff Traders in Southwestern Nigeria. American Journal Of Social And Management Sciences. Vol. 23, No.6

Eddy, Mulya. IGN. 2020. Analisis Kearifan Lokal Dalam Mewujudkan Kesejahteraan Pelaku UMKM Di Kota Denpasar. Disertasi. Denpasar. Universitas Udayana.

Ehtesham, U. M., T. M. Muhammad, and S. A. Muhammad. 2011. "Relationship Between Organizational Culture and Performance Management Practices: A Case of University in Pakistan.” Journal of Competitivenesess 4(2):76-86.

Farsi, J. Y., A. Rezazadeh, and A. Najmabadi. 2012. "Social Capital and Organizational Innovation: The Mediating Effect of Entrepreneurial Orientation." Journal of Community Positive Practices 13(2):22-40.

Friedlander, Walter. 1980. Pengantar Kesejahteraan Sosial. Jakarta: Gema Insani Press.

Fukuyama, Francis. 1999. The End of History and The Last Man: Kemenangan Kapitalisme Dan Demokrasi Liberal. Yogyakarta: Yogyakarta: Penerbit Qalam. 
Gandhiadi, G. .., Komang Dharmawan, and I. Putu Eka Nila Kencana. 2018. "Peran Pemerintah, Modal Sosial, Dan Kinerja Usaha Terhadap Kesejahteraan Subjektif Pelaku Industri Tenun Di Kabupaten Jembrana, Bali." Jurnal Matematika 8(1):2640.

Irviani, Rita. 2017. "Pengaruh Pendapatan Daerah Dan Kinerja Keuangan Terhadap Pertumbuhan Ekonomi Dan Kesejahteraan Masyarakat Pada Kabupaten/Kota Provinsi Lampung. Akuntabilitas." Jurnal Penelitian Dan Pengembangan Akuntansi 11(1):99-112.

Jaya, Putu Eka Juliana. 2020. Determinan Kinerja Produk Kreatif, Daya Saing, dan Kesejahteraan Pelaku IKM di Kota Denpasar. Disertasi. Universitas Udayana Denpasar Bali

Kaplan, Robert, S., and P. Norton, David. 1996. The Balanced Scorecard: Translating Strategy Into Action. Massachusetts: Massachusetts, Harvard Business School Press.

Keats, BW, and MA Hitt. 1988. "A Causal Model of Linkages Among Environmental Dimensions, Macro Organizational Characteristics and Performance." Academy of Management Journal 3(1):570-98.

Korry, I. Nyoman Sugawa. 2013. "The Role of Entrepreneurial Orientation in Mediating the Effect of Organizational Culture and Government Policy toward Business Performance (Case Study: Koperasi Unit Desa in Bali Province)." Journal of Business and Commerce 2(12):29-42.

Kotler, Philip. 2005. Manajemen Pemasaran, Edisi 11, Jilid 2, Edisi Terjemahan. Jakarta : Prenhalindo.

Kraus, S.Rigtering, J. C., M. Hughes, and V. Hosman. 2012. "No TitleEntrepreneurial Orientation and the Business Performance of SMEs: A Quantitative Study from the Netherlands." Review of Managerial Science 6(2):161-82.

Kretzmann, J \& McKnight, J. 1993. Building communities from the inside out: A path toward finding and mobilizing a community's assets: Chicago. ACTA Publications

Kronsbein, D., D. Meiser, and M. Leyer, 2014. Conceptualisation of Contextual Factors for Business Process Performance. Proceedings of the International MultiConference of Engineers and Computer Scientists 2014 Vol II, IMECS 2014, March 12 - 14, 2014, Hong Kong

Kusmantini, Titik, Yekti Utami dan Tri Wahyuningsih. 2011. Analisis Faktor-Faktor Kontekstual Proses Pengembangan Produk dan Dampaknya pada Kualitas Produk Baru. Jurnal Karisma, Vol.5(2): 116-128

Lee, D. .., and EW. .. Tsang. 2011. "The Effect of Entrepreneurial Personality, Background and Network Activities on Venture Growth,." Journal of Management Studies 3(8):583-602.

Luthans, F.at.al. 2007. Psychological Capital: Developing the Human Competitive Edge. New York [N.Y.]: Oxford University Press

Mauerhoefer, T., Strese, S., \& Brettel, M. (2017). The Impact Of Information Technology On New Product Development Performance. Journal Of Product Innovation Management, 34(6), 719- 738. Doi:10.1111/Jpim.12408 
Muhammad, Nurdin, Sitti Nurmaeta, and Muhammad Tahir. 2014. "Peran Pemerintah Daerah Dalam Pemberdayaan Masyarakat Petani Jagung Di Kecamatan Biringbulu Kabupaten Gowa." Jurnal Ilmu Pemerintahan Otoritas 4(1):66-78.

Munizu, Musran. 2010. "Pengaruh Faktor-Faktor Eksternal Dan Internal Terhadap Kinerja Usaha Mikro Dan Kecil (UMK) Di Sulawesi Selatan.” Jurnal Manajemen Dan Kewirausahaan (Journal of Management and Entrepreneurship) 12(1):33-41.

OECD. 2013. Guidelines on Measuring SubjectiveWell-Being. OECD Publishing.

Ozigbo, N. C. 2016. "Impact of Organizational Culture and Technology on Firm Performance in Service Sector." Communication of the IIMA 13(6):68-82.

Poudel, Krishna P., Rober Carter, and Subhash Lonial. 2012. "The Process Aspect of Entrepreneurial Orientation-Performance Relationship : Uncovering the Mediating Roles of Technological Capabilities, Innovation and Firm Growth." Frontiers of Entrepreneurship Research 32(12):1-15.

Putnam R D. 1993. "The Prosperous Community : Social Capital and Public Life, The American of Prospect, Vol 13, pp 35-42

Riddell, M. 1997. Social Capital and Policy Development. Wellington: Wellington, Institute of Policy Studies.

Sen, Amartya. 2006. Demokrasi Bisa Memberantas Kemiskinan. Bandung. Penerbit Mizan.

Simamora, Rotua Kristin, and Rudi Salam Sinaga. 2016. "Peran Pemerintah Daerah Dalam Pengembangan Pariwisata Alam Dan Budaya Di Kabupaten Tapanuli Utara." Jurnal Ilmu Pemerintahan Dan Sosial Politik 4(1):79-96.

Steurer, R. 2010. "The Role of Governments in Corporate Social Responsibility: Characterising Public Policies on CSR in Europe." Journal of Policy Sciences, 43:49-72.

Suasih, Ni Nyoman Reni. 2016. Analisis Determinan Kesejahteraan Petani (Studi Kasus Di Subak Pulagan, Desa Tampaksiring, Kabupaten Gianyar. Disertasi. Denpasar: Universitas Udayana Denpasar.

Sudaryanto, Sudaryanto. 2011. "The Need for ICT-Education for Manager or Agribusinessman to Increasing Farm Income: Study of Factor Influences on Computer Adoption in East Java Farm Agribusiness." International Journal of Education and Development, JEDICT 7(1):56-67.

Swastika, I. P. D., M. K. S. Budhi, and M. H. U. Dewi. 2017. “Analisis Pengembangan Agrowisata Untuk Kesejahteraan Masyarakat Di Kecamatan Petang, Kabupaten Badung." E-Jurnal Ekonomi Dan Bisnis Universitas Udayana 6(12):4103-36.

Triadhi, Nyoman Andika. 2019. Pengaruh Budaya Tri Hita Karana, Pemberdayaan, Kewirausahaan, Dan Kelembagaan Terhadap Kesejahteraan Nelayan Di Pulau Serangan. Disertasi. Denpasar, Fakultas Ekonomi dan Bisnis, Universitas Udayana.

Widiastuti, Ratna dan Margaretha, Meily. 2011. Socio Enterpreneurship: Tinjaun Teori dan Perannnya Bagi Masyarakat. Jurnal Manajemen, Vol.11, No.1

Wright, T. A., \& Bonett, D. G. 2007. Job Satisfaction and Psychological Well-being as 
Jurnal Cahaya Mandalika, Vol. 3, No. 1, 2022 ,e- ISSN: 2721-4796

Available online at: http://ojs.cahayamandalika.com/index.php/JCM

Copyright (c) 2021 Publisher: Institut Penelitian \& Pengembangan Mandalika Indonesia

Nonadditive Predictors of Workplace Turnover. Journal of Management, 33(2), $141-160$

Yuliarmi, Ni Nyoman, Agus Suman, S. M. Kiptiyah, and Ahmad Erani Yustika. 2012. "The Role of Government, Traditional Institution, and Social Capital for Empowering Small Medium Industries." Journal of Economics, Business, and Accountancy Ventura 15(2):205-18. 